\title{
7
}

\section{'OPEN BORDERS'}

\section{A postcolonial critique}

\author{
Gurminder K. Bhambra
}

\section{Postcolonial challenges to spatialisation}

Our times are marked by the unprecedented attention given to the movement of people. This has been highlighted in recent years as a consequence of what is generally called the 'refugee crisis' in Europe. However, I prefer to see it as the crisis produced for refugees by our-that is, European-failure to abide by the norms and obligations set out in various international human rights treaties to which we are signatories. For all the attention—-media and political—given to this movement of people, one would expect the ensuing numbers to be far in excess of the $0.31 \%$ increase in the total population in Europe that successful asylum applications have otherwise constituted over the last few years (Bhambra 2017a). Even if we were to add the numbers of those who come for what are termed 'economic' reasons, the movement of people in our contemporary times is far smaller and less significant in terms of its impact on land and local people than earlier movements. Here, I am alluding to the mass movement of Europeans from the seventeenth century onwards to what came to be known as the New World.

Indeed, across the nineteenth century and into the twentieth, over 60 million Europeans moved to the lands of others, far exceeding in scope and impact the numbers moving today (Miège 1993). Europe could, but for the most part chooses not to, absorb others into its societies; however, they were forced to give way to Europeans and to their domination over them. Yet, almost without exception, those writing on migration today do so without any reference to that earlier movement. Nor do they understand how it is part of the explanation of contemporary inequalities and, as such, would need to be part of any solution.

Even those commentators on public policy who see migration as the most effective way to address issues of global inequality — such as Branko Milanovic (2016) do so through a presentist lens, which sees migration primarily in terms of the 
problems posed by 'open borders' for the host societies. It is in this context that Milanovic (2016), formerly lead economist in the World Bank's research department, proposed in an op-ed in the Financial Times whether a trade-off might not be made between citizenship and migration to resolve this contradiction. He argues that while open borders are likely to be the most effective way of reducing global inequality, this would require a trade-off between citizenship and migration on the part of those moving; they might be allowed to move, but they should be denied citizenship and the associated rights.

In contrast, as I will go on to argue, the postcolonial challenge to the contemporary spatialisation of modernity requires us to consider the extent to which our current neoliberal times reproduce earlier colonial logics that facilitated movement for some while establishing hard borders for others. As Knoblauch and Löw (2017) argue, modernity can be seen in terms of violent processes involving the extension and enforcement of boundaries and the homogenisation of spaces and populations. The solution to the identified problems consequent to this spatialisation of the world does not, for me, rest on the idea of 'open borders', particularly as this is being conceptualised by some economists. Nor does it lie in the alternative promoted by those such as Wolfgang Streeck (2018) of a hostile environment for migration and refugee aid close to the source. Rather, it lies in a collective accountability that can only be met through a process of social democratic reparative action; that is, through a generalising of social democracy rather than the establishment of a nationally specific social democracy available to some but denied to others.

\section{Global inequality, open borders, and differential citizenship}

The idea that issues of global inequality can be addressed through the movement of individuals across open borders in conjunction with limiting the rights of those who move has been put forward by a number of economists and other scholars. Eric Posner and Glen Weyl (2014, np), for example, argue that 'the most powerful force to reduce inequality worldwide' is a system of 'open migration laws that are coupled, paradoxically, with caste systems'. They suggest that we look to the Gulf nations, which, by welcoming migrant workers, 'do more than any other rich country to reduce global inequality'. They recognise that migration to these countries is facilitated by limiting the rights of migrant workers in these authoritarian states; but suggest that 'reducing inequality will require uncomfortable tradeoffs'. Branko Milanovic (2016) similarly aligns himself with this position.

Milanovic (2018) sees the problems associated with the movement of people as resting in two phenomena. First, that globalisation has made knowledge of income differentials between countries better known and, relatedly, that transportation costs are much lower than was previously the case. Second, that there are increasing gaps in real incomes between wealthy countries and poorer ones. Milanovic (2018) argues that, whereas previously the locus of global inequality could be identified in class differences, as had been argued by Marx and Engels, it now rests in aspects of location. While the available datasets from the nineteenth century confirm Marx 
and Engels' assumptions about the 'similarity in the economic position of workers across the world' (Milanovic 2012, 126-127), Milanovic suggests that this changes by the early twenty-first century. At this point, he argues, inequality comes to be predominantly determined by geographical location and not economic class. That is, as he states, the poorest citizens in the richest countries have incomes higher than the richest citizens in the poorest countries. It is this income differential across locations that drives people to migrate because, as he argues, 'people can increase their incomes several fold if they migrate from a low mean income location to a high mean income location' (Milanovic 2012, 130).

As such, Milanovic (2016, np) claims that 'migration does more to reduce global poverty and inequality than any other factor', but that the problem with this solution is that the 'arrival of migrants threatens to diminish or dilute the premium [generally understood in terms of access to the welfare state] enjoyed by citizens of rich countries', who are then hostile to the new arrivals. In part, he argues, this is a consequence of those who are the poorest in rich nations being 'the biggest losers' of globalisation (Milanovic 2013, 202). The shift from the end of the twentieth century to the early twenty-first century saw real incomes rise for almost everybody globally, except for the very poorest $5 \%$ or those within the " 75 th and 90 th percentiles of global income distribution, whose real income gains were essentially nil' (Milanovic 2013, 202). These people-on lower incomes in rich countries, whose income has not increased, but who are still part of the $25 \%$ of highest earners in the world-are presented by Milanovic as the 'nonwinners' of globalisation and as the people most likely to be threatened by and hostile to immigration. And whose hostility has been acknowledged as legitimate.

Milanovic (2018), somewhat inconsistently, concedes that there is only a slight negative impact on wages as a consequence of migration from poorer countries. This suggests that domestic policy rather than globalisation might explain the stagnant incomes of the 'nonwinners' of the West. However, it is the cultural impact that he treats as significant and requiring accommodation. That is, he suggests an approach is needed that would balance the economic needs of a country for migrants 'with the preservation of certain cultural norms' (Milanovic 2018), as if migrants necessarily disrupt those norms. This could be done by restricting migration to those workers who 'come to do specific jobs for a limited period of time' and who would then return to their countries of origin (Milanovic 2018). Another solution would be to restrict the citizenship rights of migrants in the countries of arrival and make them pay higher taxes given the benefits they gain by being granted entry to these countries. This, Milanovic (2016, np) argues, would 'assuage the concerns of the native population, while still ensuring the migrants are better off than they would be had they stayed in their own countries'.

Notice that the world's poorest are asked to pay taxation to support those within the 75 th to 90 th percentile, while the top 10th percentile appropriates the profit from their exploited labour and has experienced a significant reduction in their tax burden. It is the world's poorest who, as a price for their mobility, are asked to pay taxes for services for others - to which they themselves are denied access-as 
well as a further tax (or rent) for simply working in wealthier countries. This is Milanovic's compromise solution, which, he suggests, is 'in tune with globalisation but also with legitimate concerns for national heritage' (Milanovic 2018, np). As I will go on to argue, this compromise solution is only a solution in the context of accepting neoliberal norms and precepts as defining not only our contemporary times, but also our normative understandings.

\section{Indenture as a 'choice' to reduce global inequality}

Eric Posner and Glen Weyl (2014, np) state quite openly that 'Gulf states explicitly seek non-Arab, dark-skinned migrants so as to minimize the risk that nationals will sympathize, fraternize, or intermarry with migrants (who would then demand permanent residence, if not citizenship)'. Further, they suggest that migrants should be paid significantly lower wages than those typical of even low-paid workers in the host society. They must also be deprived of rights to organise and protest, and are to be delivered into a strict subordination to employers as indentured labour. While the exploitation of indentured labour will be to the benefit of employers (and some consumers) in the north, they claim that it will also be to the betterment of indentured labourers themselves, who are escaping the worse conditions they otherwise face 'at home'.

This, as I have argued with John Holmwood (Holmwood and Bhambra 2015) elsewhere, is a 'pro-slavery' argument for the free movement of unfree labour. Significantly, Posner and Weyl seem to repeat arguments last articulated in defence of Jim Crow policies in the southern states of the United States of America, specifically that slavery itself was relatively beneficial for transported Africans compared with the circumstances in Africa from which they came. Quite apart from the distasteful nature of the argument, its sociological or political naivety is also evident. They write as if the colonial process of enslavement had no impact upon the populations that were left behind in terms of their possibilities for subsistence and collective determination (see Manning 1983; Lovejoy 1989). 'Belonging', and with it the right to have social and political rights, is presented as a privilege of local (European and European-descended) citizens; migrants are displaced from where they belong and are to be offered no recognition or rights in the places to which they move.

This is exacerbated by Posner and Weyl's (2018) further proposal for relatively disadvantaged citizens in wealthy countries to be able to 'sponsor' or 'rent' migrants as a way of binding them to the overarching project of alleviating global poverty by providing them with a direct return. They explicitly advocate for a segregated system dependent on patronage and enforced through the maintenance of ascribed differences (see also Weyl 2016). Domestic capital should be free to exploit indentured labour, while migrant labour should be policed and prevented from claiming rights enjoyed by other citizens (though it is unlikely that local populations in the global North could be insulated from the effects of divided citizenship and merely enjoy the fruits of the indentured labour in the form of rent or cheap services). In effect, they implicitly recognise that enforcing cheap labour creates a windfall 
profit for those who can access it, but seeks to resolve that inequality by widening the pool of exploiters. This represents not so much a universal basic income as a racialised income supplement.

Such arguments are contingent upon the idea that the global North bears no collective responsibility for the conditions found in the global South. The issues are framed simply in terms of our charity and benevolence towards others in constrained circumstances with little reflection on how we may be responsible for the commission and maintenance of those very circumstances. Furthermore, it relies on the notion that, however constrained, indentured labour represents a 'choice'. The question that we must ask, however, is at what point does 'indentured labour' become so constrained that it represents enslavement? As Chris Bertram argues, such a posited solution 'distorts our moral understanding, specifically, our understanding of justice, to represent a pragmatic compromise with unjust attitudes as exemplifying what justice itself demands' $(2019,290)$. Further, denying rights to alleviate global inequality, he continues, 'when we could achieve the same outcomes by acting otherwise, involves the [active] commission of injustice' (2019, 295). Global inequality is not a natural condition that requires 'us' to address it through acts of willed generosity; instead, it requires a more thoroughgoing understanding of its production and our related obligations as a consequence of this shared and unequal history.

\section{Histories of global inequality}

There is a general recognition that the process of moving as a means of addressing issues of local impoverishment and inequality is not new. Yet, there is little discussion of how that migration - what used to be called in nineteenth-century German national economy 'emigrationist colonialism' (Smith 1980)_-itself contributes to the process of creating the vast differentials between incomes on a global scale. Today, European and North American debates make no reference to colonialism and scarcely allude to that movement of people, for the most part Europeans, who, whether intentionally or not, come to be part of the project of settler colonialism and the processes of dispossession, elimination, and extraction that have significantly contributed to the specific configuration of contemporary inequalities.

Across the nineteenth century, as mentioned earlier, around 60 million Europeans left their countries of origin to make new lives and livelihoods for themselves on lands inhabited by others (Miege 1993). Each new cohort of Europeans was allocated land at the edges of the territory that had already been colonised. This was done in order to extend political control over contested border territories. In this way, Europeans from across the continent participated in the elimination and dispossession of the populations who were on that land and were thus complicit in the settler colonial project.

At least 7 million Germans moved to these lands - to what was to become the United States in the north and to Brazil and Argentina in the south-becoming, by the late nineteenth century, one of the largest immigrant groups in the north 
(Bade 1995). Large-scale Polish emigration started in the period after the FrancoPrussian war, and by the turn to the twentieth century, over 2 million Polish people had moved to the Americas, with about 300,000 settling in Brazil, another settler colony, by 1939 (Zubrzycki 1953). Two million subjects of the Dual Monarchy of Austria-Hungary travelled to the Americas (Zahra 2016), as did over 8 million Irish people (Delaney 2000) - including a million as a consequence of the mid-century famine induced by British colonial rule. By 1890, nearly a million Swedes, onefifth of the total Swedish population, were living in the lands colonised by (and as) the U.S. In addition, 13.5 million British people moved to white settler colonies across the globe (Fedorowich and Thompson 2013). National migration associations were set up to facilitate the movement of poor and unemployed Europeans to the New World and beyond. Those who left remitted money back, pointing to the ways in which the wealth accrued through colonial endeavours was directly linked to the development of the economy, and particularly local economies, 'back home'. European empires also taxed the peoples they dominated, appropriating not only a surplus for the management of the colony, but also a surplus for the building of state institutions in the metropole, what Milanovic calls the "national patrimony'.

The movement of peoples, of such magnitude, is implicitly claimed to have been unproblematic and in some of the literature is called the age of 'free migration', referring to the 'open border' of the United States during most of this period. Milanovic, for example, suggests that the issue in terms of people's movement today, as compared to movements in the past, is that today 'the impediments are greater' $(2012,131)$; that is, there are walls, barriers, fortified borders, which there had not been in the past. This appears to suggest that the mass European movement of the nineteenth century occurred without any contestation. What is not accounted for in such a presentation is the preceding movement, also of Europeans, that had largely eliminated the prior populations of these lands to enable them to be seen as 'free soil', to use Weber's term (quoted in Mommsen 1984 [1959], 83, fn 56). The 'open border' of the United States might have been open on the eastern edge, but this was only as a consequence of Europeans having eliminated indigenous peoples and appropriated their lands. It was not 'open' prior to being made so through European colonisation.

As such, not only are European imperial powers implicated in the production of global inequalities, but also broader European populations who, by moving to these lands, consolidated the 'manifest destiny' of expansion at the expense of the prior inhabitants.

This earlier movement of people was different to contemporary migration not least because those who move across borders in the present live according to the rules and norms of the societies of the lands to which they come-this was not the case with Europeans moving to the lands of others. Those who moved in the age of 'free migration' are better understood as colonial settlers, and colonial settlers are not migrants even if much of the scholarship confuses them as such. To naturalise the historical processes of conquest and colonisation as 'migration' normalises 
and legitimates violence in the past as the condition for continued violence against others in the present (who bear that violence as their 'patrimony'). The violence of imperial rule and colonial settlement disappears from histories of the nationhappening, as it does, outside of the borders of the national state - at the same time as arguments about national sovereignty and national heritage are used to securitise borders in the present and to argue for differentiated citizenship for those with the temerity to move across them. Milanovic (and others, such as Streeck) argues for a legitimate national heritage and perceives problems in the integration of difference, yet it is colonialism itself that racialised difference and made it difficult to consider treating 'diverse others' as equals. On this, there is little to no comment.

\section{European colonisation and the production of global inequality}

Milanovic $(2012,132)$ is not unaware of Europe's long history of colonisation; it is just that he euphemises the process as one whereby Europe 'exported its people elsewhere'. As such, he does not seem to regard it as significant to the shaping of the world or to the establishment of inequalities within it. For example, he states that India, today, similar to China, 'is also recording high rates of growth and has also started from a very low baseline' (Milanovic 2013, 200). This is presented without any comment about the drain of resources that had occurred from India to Britain over two hundred years of colonial rule (Patnaik 2017) and the similar practices imposed upon China by the West to create the 'very low baseline'. Instead, in their modelling of incomes over time, economists use national categories to discuss territories that were in fact colonised. For example, Milanovic $(2013,205)$ writes that Marx's presentation of proletarians in different parts of the world - that is, 'peasants in India, workers in England'-sharing the same political interests was 'a broadly accurate description of the situation at that time'. This is because, he states, 'equally poor people of different nations faced equally rich people in their own' (Milanovic 2013, 205). This rather neglects to address the fact that peasants in India were not being exploited by rich people within their 'nation', as India was at that time under colonial rule exercised by Britain and the profits of exploitation were appropriated by the colonial power, and only partly by local elites.

This form of methodological nationalism - or what I have also called 'methodological whiteness' (Bhambra 2017b) —within the social sciences, while leading to inadequate scholarship in its own terms, also has pernicious consequences in the debates on migration and citizenship. Milanovic, for example, states that the reason poor migrants should not have access to full citizenship rights is because it would be viewed as unfair by local citizens whose 'citizenship premium' would be diminished. This is because, as he states, rich countries accumulate wealth and transmit it 'along with many other advantages, to the next generations of their citizens' (Milanovic 2013, 207). 'We take it as normal,' he suggests, 'that there is a transmission of collectively acquired wealth over generations within the same nation' (Milanovic 2013, 207) and for the enjoyment of its citizens. But, if as I have 
been arguing, European states were not constituted simply as nations, but as imperial powers, and that a significant proportion of what is presented as their national wealth historically is attributable to the coerced labour and appropriated resources of others, then what does it mean to argue for the protection of that wealth solely for one's own citizens? Notice, too, that Milanovic is also silent on the decline of that public capital through policies of privatisation.

The idea that most European countries were simply nations, generating wealth endogenously, is a fundamental misreading of the historical processes that produced Europe. Even those countries that are not explicitly regarded as having been colonial powers partook nonetheless in the wealth of the European colonial project through the involvement of their populations in emigrationist colonialism and through being the beneficiaries of 'colonial drain' (Patnaik 2017). The wealth that is claimed by nations in Europe has a much broader provenance and, if we were to accept this, then we might be persuaded to reconfigure our politics in the present such that addressing global inequality would not require a trade-off between social and political citizenship and migration. Even Milanovic (2018) recognises that there are other ways to address global inequality, including global redistributive schemes. He just does not believe that such a scheme would be feasible. I would argue, in contrast, that not only is such a scheme feasible and just, but also that it is the only way in which we can tackle the confluence of neoliberal and the increasingly authoritarian politics of the present.

\section{Conclusion: for postcolonial reparative action}

European colonialism was a collective and individual endeavour that established, determined, and perpetuated the forms of global inequality that continue to disfigure our contemporary world. Its address requires us to acknowledge the ways in which we benefit from this structuring of the world and act to resolve those structures in a fully inclusive and social-democratic, not a nationalist, way. The injustices that disfigure the world we share can only be addressed by acknowledging the histories that have produced them as well as the historiographies that have obscured them.

This requires reflection upon the past and what I call postcolonial reparative action in the present. Perhaps unconditionally accepting refugees, asylum seekers, and other migrants to Europe would mitigate the actions of earlier generations that have precisely made the places 'they' come from unliveable? Could rethinking and reformulating trade and other policies, which are entirely to Europe's advantage, be an act of reparative justice? Might relabelling 'aid' as 'reparations' create the space for conversations about how little Europe gives and how much of what is given returns to Europe anyway and facilitate the possibility of doing more?

Europe is the wealthiest continent on the planet. Its wealth is an 'inheritance' derived from the very same historical processes that have left other places in poverty. Migration is an inadequate solution to the problem of global inequality. The problem of global inequality has itself been configured as a consequence of earlier 
European movements. The only effective solution to issues of global inequality is to acknowledge and address these histories through forms of global distributive justice.

\section{References}

Bade, K. 1995. 'From Emigration to Immigration: The German Experience in the Nineteenth and Twentieth Centuries.' Central European History 28 (4): 507-535.

Bertram, Chris. 2019. 'The Openness-Rights Trade-off in Labour Migration, Claims to Membership, and Justice.' Ethical Theory and Moral Practice 22 (2): 283-296.

Bhambra, Gurminder K. 2017a. 'The Current Crisis of Europe: Refugees, Colonialism, and the Limits of Cosmopolitanism.' European Law Journal 23 (5): 395-405.

Bhambra, Gurminder K. 2017b. 'Brexit, Trump, and "Methodological Whiteness": On the Misrecognition of Race and Class.' British Journal of Sociology 68 (S1): 214-232.

Delaney, Enda. 2000. Demography, State and Society: Irish Migration to Britain, 1921-1971. Liverpool: Liverpool University Press.

Fedorowich, Kent, and Andrew S. Thompson. 2013. 'Mapping the Contours of the British World: Empire, Migration and Identity.' In Empire, Migration and Identity in the British World, edited by Kent Fedorowich and Andrew S. Thompson, 1-41. Manchester: Manchester University Press.

Holmwood, John, and Gurminder K. Bhambra. 2015. 'Capitalist Dispossession and New Justifications of Slavery,' Open Democracy, July 3. www.opendemocracy.net/en/ beyond-trafficking-and-slavery/capitalist-dispossession-and-new-justifications-of-s/.

Knoblauch, Hubert, and Martina Löw. 2017. 'On the Spatial Re-Figuration of the Social World.' Sociologica 11 (2): 1-27. doi: 10.2383/88197.

Lovejoy, Paul. 1989. 'The Impact of the Atlantic Slave Trade on Africa: A Review of the Literature.' The Journal of African History 30 (3): 365-394.

Manning, Patrick. 1983. 'Contours of Slavery and Social Change in Africa.' The American Historical Review 88 (4): 835-857.

Miège, Jean-Louis. 1993. 'Migration and Decolonisation.' European Review 1 (1): 81-86.

Milanovic, Branko. 2012. 'Global Inequality: From Class to Location, from Proletarians to Migrants.' Global Policy 3 (2): 125-134.

Milanovic, Branko. 2013. 'Global Income Inequality in Numbers: In History and Now.' Global Policy 4 (2): 198-208.

Milanovic, Branko. 2016. 'There is a Trade-off between Citizenship and Migration.' Financial Times, April 20.

Milanovic, Branko. 2018. 'Migration into Europe: A Long-Term Solution?' Social Europe, November 19.

Mommsen, Wolfgang J. 1984. Max Weber and German Politics 1890-1920. Translated by Michael S. Steinberg. Chicago: University of Chicago Press.

Patnaik, Utsa. 2017. 'Revisiting the "Drain", or Transfer from India to Britain in the Context of Global Diffusion of Capitalism.' In Agrarian and Other Histories: Essays for Binay Bhushan Chaudhuri, edited by Shubhra Chakrabarti and Utsa Patnaik, 277-317. New Delhi: Tulika Books.

Posner, Eric A., and Glen Weyl. 2014. 'A Radical Solution to Global Income Inequality: Make the U.S. More Like Qatar.' The New Republic, November 7. https://newrepublic.com/ article/120179/how-reduce-global-income-inequality-open-immigration-policies.

Posner, Eric A., and Glen Weyl. 2018. Radical Markets: Uprooting Capitalism and Democracy for a Just Society. Princeton: Princeton University Press. 


\section{Gurminder K. Bhambra}

Smith, Woodruff D. 1980. 'Friedrich Ratzel and the Origins of Lebensraum.' German Studies Review 3 (1): 51-68.

Streeck, Wolfgang. 2018. 'Between Charity and Justice: Remarks on the Social Construction of Immigration Policy in Rich Democracies.' Culture, Practice and Europeanisation 3 (2): 3-22.

Weyl, Eric Glen. 2016. 'The Openness-Equality Trade-Off in Global Redistribution.' The Economic Journal, October 25. https://ssrn.com/abstract=2509305.

Zahra, Tara. 2016. The Great Departure: Mass Migration from Eastern Europe and the Making of the Free World. New York: W. W. Norton and Company.

Zubrzycki, J. 1953. 'Emigration from Poland in the Nineteenth and Twentieth Centuries.' Population Studies 6 (3): 248-272. 